\title{
FIGURATIVE LANGUAGE IN SONG LYRIC “RED” BY TAYLOR SWIFT
}

\author{
Dianti Dini Rahmani ${ }^{1}$, Sukma Septian Nasution ${ }^{2}$ \\ Universitas Pamulang \\ diantidinirahmani@gmail.com
}

\begin{abstract}
Observing the figurative language in a song lyric entitled "Red" by Taylor Swift, this study aims at (1) finding out kinds of figurative language and (2) analyzing the appropriate intent of figurative language Taylor Swift's song. This study uses a song from the fourth Taylor Swift's album called Red. This study employs qualitative methods in data collection. After collecting the data, it encompasses that simile and hyperbole are dominantly found. It also reveals that figurative language used in this song is to deliver her deepest feeling. The use of figurative language in this song is very dominant which can provide knowledge to the reader to know the type of figurative language.
\end{abstract}

Keywords : Figurative language, Hyperbole, Simile, Song Lyric.

\section{INTRODUCTION}

Language has current variations. As time goes on, languages and literature are increasingly developing and have lots of variations. The development of the language makes the language have its own color, but the meaning of color here is not like the primary or secondary color that we already know is still the color in this language is a figurative language. Figurative language makes the language more colorful, varied and beautiful like art.

The language itself has a big role in our life. People use language in any sector, for example, people use language for communication, interaction like negotiating and bargain. According to Harmer (2007) said that language is applied broadly between people to communicate with each other. Language has an important role to make a relationship with others. Therefore, due to people use the language every time to communicate with others from a different background, language develop and create a variation, one of the language variations is Figurative Language.

People use variated language to simplify meaning that suitable with the condition. People use figurative languages such as personification, hyperbole, simile, metaphor and many more to convey their ideas not only in speaking but also in writing easier. According to Abrams (1999: 96), it is told that figurative language is the use of language that is striking by language users and understood as the standard meaning of words, to attain some special meaning or effect. Figurative language sometimes becomes an alternative for someone to convey an implied message to be easier to understand by listeners.

Perrine (1982) said that figurative language is defined as a way of saying 
things in a different way than usual. The use of figurative language is used by someone to express their thoughts by being different from ordinary people. In this way we will know the person's personality in addressing a problem the speaker is facing by raising his opinion using figurative language so that the listener must think about what the speaker means because when someone communicates, they better implement cooperative principles which must understand and work together in conversations with how to understand the personality of the interlocutor and also understand what he says even in figurative language.

As we know, the song is a form of literary works. A song is a music with meaningful words from the author. The song is a combination of melody and vocals, as well as some composers, have written instrumental works. The words of a song are called lyrics. Lyrics can include a series of verses usually telling the story of the author. In the lyrics of the song usually contains the outpouring of the author's heart. The song became popular and liked by many people due to its melodies that were pleasant to hear and the lyrics were touching. Moreover, people like it more if the lyrics written by the composer are based on the experience of the composer.

One of the various ways to understand the intentions of the other person to avoid the allegations of the other person is to use figurative language. In song lyrics "Red" by Taylor Swift is telling about a love story and she described the song by the color. The use of color to describe the composer's feeling is one type of language variation which can be called a figurative language. The use of figurative language is very creative and attracts writers to analyze it.

This song is Taylor Swift's own creation which is her personal experience and most of her songs are her own creations and are made based on her experience in a love relationship. In his latest interview with Elle UK magazine, the Delicate singer recounted the reason for having written a song, "I like writing songs because I can keep memories like putting a picture frame that contains your feelings. I like using nostalgia as inspiration when writing songs and the same reason I like taking photos," said Taylor Swift. Taylor Swift really likes to remember things in detail. So when writing a song he will remember all the memories from the color of the clothes to the air in great detail.

Similar study has actually been conducted such as by Sadiasih, Ni Komang Putu Mulya Dewi, Putu Chrisma (2016) conducted a study entitled "Figurative Language in Song Lyrics By Rihanna and Katy Perry" it was disseminated in University of Dhyana Pura. The objectives of the study are to identify and to analyze the figurative language and the important concept idea in song lyrics of Rihanna and Katty Perry. Based on the study research, it was found that the study shows six types of figurative language, namely hyperbole, simile and metaphor in Rihanna song lyrics and personification, hyperbole, simile, paradox, metaphor, and irony in Katy Perry song. The similarity of both studies is the same as analyzing the figurative language on Taylor Swift song. Moreover, in the Taylor Swift song, the same gets 3 kinds of figurative languages which are similar namely simile, metaphor and hyperbole.

The difference is the related studies are analyzing the figurative language in the song Taylor Swist and Katty Perry. Moreover, in the related study found more types of figurative language namely personification, paradox, and irony.

Another related study that appropriate is from Siallagan, Sari Rishita Manurung, Sulastri Sinaga and Juwita Boneka (2019) conducted a study entitled "Analysis of Figurative Language and Imagery in Taylor Swift's Songs" it was written in Anglo-Saxon: English Language 
Scientific Journal Study Program. The objectives of the study are to find out the kinds of figurative language and imagery in the song lyrics of Taylor Swift's "1989" Album. Based on observation, it was found eight kinds of figurative languages in the songs lyrics, namely, personification, metaphor, hyperbole, simile, oxymoron, allusion, litotes, and metonymy. Six kinds of imagery also found in the songs lyrics, namely, visual imagery, auditory imagery, organic imagery, kinesthetic imagery, tactile imagery, and olfactory imagery. The similarity of both studies is the same as analyzing figurative language in Taylor Swift's song. The difference of both studies is the related study analyzing not only figurative language but also imagery of the song. Moreover, it found more type of figurative language namely personification, oxymoron, allusion, litotes, and metonymy.

The last example of a related study that corresponds is from Syahrul Efendi Lubis (2017) conducted a study entitled "An Analysis of Figurative Language in the Song Lyric "Diamonds" sung By Rihanna" it was written in Cohesion Scientific Journal. The objective of the study is to give assistance to the reader to know about figurative language palpably. Based on the observation, it was found some types of figurative languages, such as 1. Simile, 2. Repetition, 3. Imagery, 4. Metaphor, 5. Alliteration, 6. Metonymy, 7. Hyperbole, 8. Personification, 9. Assonance. The similarity of both researches is the same analyzing figurative language in song. The difference of both studies is the related study is analyzing "Diamonds" sung By Rihanna and it found more types of figurative language such as repetition, imagery, alliteration, metonymy, personification, and assonance.

\section{METHOD}

The way to find out the objectives of the study by the writer was first to read the song's lyrics Red by Taylor Swift and understand nicely about figurative language. Figurative language is kinds of a word that has an implicit meaning. This figurative language can be analyzed by using a qualitative method. According to Moleong (2010), qualitative methods are research techniques that can obtain descriptions of words and performance that can be researched by people. The use of a qualitative method is by collecting the data from the object and explain it in detail to greatly solve the available problem to achieve the aims.

\section{DISCUSSION}

Rozakis (1995) says that "Figurative language expresses one thing in another than usual to achieve special meaning". It means that figurative language is a method used by people or writers to convey their intentions indirectly. This figurative language cannot be interpreted with the true meaning, the writer must first find out what is meant by the author regarding the intent. Based on the song lyrics Red by Taylor Swift, the writer found several kinds of figurative language that are Simile, Metaphor, and Hyperbole. There are 13 data that the writer found, but only 9 data which is analyzed. Namely, 3 words simile, 3 words metaphor and 3 words hyperbole.

\section{Simile}

According to Keraf (2001) Simile is an explicit comparison. It means that simile is a comparison between two different words explicitly that have certain intentions. In song Red by Taylor Swift there are several figurative languages, but this section will wrestle one kind of figurative language namely, simile. As explained by the expert above, this simile deals with a comparison between two words that have special meaning. In song Red by Taylor Swift song there are several Simile that can be found, but the writer takes 3 examples that can be analyzed

"Loving him is like driving a new Maserati down a dead-end street" 
In some music, composers often use comparisons in figurative words whose names we already know are simile by combining comparative words using comparative words: "as if, like, like," etc. In the lyrics above using the word "like". Therefore, the utterance is a simile because they compare two things between "loving him" and "driving a new Maserati in a dead- end street" and as a reference, Rozakis (1995) who said that that "Figurative language expresses one thing in another than usual to achieve special meaning "in the words above, Taylor Swift uses another word than the real intention to get an effect meaning.

"Touching him was like realizing all you ever wanted was right there in front of you"

As said by Keraf (2001) Simile is an explicit comparison. A sign of utterance is a simile category, the expression has the word "like" which indicates a comparison between things. The above statement explicitly explains that Taylor "touching him" he was the man Taylor loved and compared with the word "realizing all you ever wanted was right there in front of you" Taylor intends to describe what she felt when touching him was like a fun thing what she wants is in front of her eyes. This is because Taylor wants to show that she is very happy to touch the man she loves. As explained by Rozakis (1995) who said that that "Figurative language expresses one thing in another than usual to achieve special meaning.' Taylor uses a figurative language to explain to the listener something clearly and in detail what he feels. Taylor wants to make the listener feel what she feels. Therefore, she uses a figurative language that is using other words to achieve the special meaning.

"Fighting with him was like trying to solve a crossword and realizing there's no right answer"

A simile is a comparison between two different words that explicitly has certain intentions. in the utterance above is included in the simile category because it uses the word "like" which means Taylor is comparing something namely "Fighting with him" Taylor wants to describe that she was fighting with a man she loved is like "trying to solve a crossword puzzle and realize there's no right answers" Taylor meant here instead she could not find the right answer to the crossword puzzle but what she meant here was that she was very uncomfortable and frustrated when fighting with the man she liked. As explained by the expert, Rozakis (1995: 28) that "Figurative language expresses one thing in another than usual to achieve special meaning". Taylor wrote songs using figurative language, which is an utterance that is different from usual in order to achieve special effects to the listener with the aim that she wants the listener to understand what she feels by imagining that if she doesn't get the right answer while playing puzzles, the feeling is frustrating.

\section{Metaphor}

Peter (2002) said that metaphors are figurative words, which compare one thing to another without using the word "like" or "as" or comparing it directly. Metaphor is a type of figurative language that describes an object with direct and precise comparisons on the basis of the same or almost the same nature as other objects. In song Red by Taylor Swift, the writer found 3 metaphors in which Taylor described it using colors that had the same characteristics as the word he intended.

"Losing him was blue like I'd never known"

A metaphor is an analogy that compares two things directly. The phrase "Losing him is blue like I'd never known" is comparing "losing him" is Taylor's feeling that losing a loved one with "blue" has an analogy that describes sadness. Two things implied in the lyrics above illustrate that Taylor wants to describe her relationship with a man, namely the relationship when she loses her male she 
will feel deep sadness by describing it with color, and colors that have a relationship with sadness is blue, so Taylor uses blue as a picture of sadness when she loses the man she loves. As has been said by experts, Rozakis (1995) says that "Figurative language expresses one thing in another than usual to achieve special meaning" Taylor uses another language than the usual word to describe clearly what she feels when losing someone she loved by using colors, that are blue.

"Missing him was dark grey all alone"

Metaphor is a method is a type of figurative language that compares an object directly. In comparing something metaphor has the same nature as other objects. In the words above "Missing him" is when Taylor misses the man she loves and compares it to the color "dark gray" which has an analogy to depression. Taylor uses figurative words to express meaning by emphasizing the impression that will be caused. As the expert said, Rozakis (1995: 28) that "Figurative language expresses one thing in another than usual to achieve special meaning" Taylor uses other meaningful words to explain to listeners that the above statement is written so that listeners understand what Taylor feels.

"But loving him was red"

Peter (2002) says that metaphor is a figurative word, which compares one thing to another without using the word "like" or "as" or comparing it directly. In the above utterances, Taylor writes "loving him" which is when she loves her male she compares directly using color, which is red. Red has analogies like happiness, glad, delight, joy, and love. Taylor described that she loved him with feelings of pleasure, gladness, delight, and joy. Therefore, according to expert namely Rozakis (1995: 28), he says that "Figurative language expresses one thing in another than usual to achieve special meaning". Taylor in writing songs expresses it in other words that have a meaning similar to the subject and in expressing it with emphasis so that the intentions conveyed by Taylor are conveyed clearly and there is an impression that is caused.

\section{Hyperbole}

Dennis (1996: 65) states that hyperbole is a figure of speech that has a statement that has excessive meaning for its true intentions. Hyperbole is a figurative language that exaggerates what is actually with the intention of intensifying, increasing the impression and power of influence, both in number, size, and characteristics. In our daily lives we often find this figurative language when talking to someone to get a dramatic impression and done with the aim to attract the attention of the listeners. In song Red by Taylor Swift song there are several figurative languages that fall into the category of hyperbole, but the writer only takes 3 utterances to analyzed.

"Loving him is like trying to change your mind once you're already flying through free fall"

Hyperbole is one figure that implies excessive ideas. In "trying to change your mind" it means changing the condition or situation, but "once you've flown through free fall " is considered a condition that has happened.

Basically, humans cannot change something that has happened in the past. In the lyrics above there is an excessive statement to love someone that is you want to change your mind when you have fallen free. This is excessive and impossible. However as the expert statement mentioned above, Rozakis (1995: 28) says that "Figurative language expresses one thing in another than usual to achieve special meaning". Taylor's intention to use words that are different from the true meaning is to describe how much Taylor had loved him and could not forget all his memories with him and even made a special connection with him.

"Forgetting him was like trying to know somebody you've never met" 
Hyperbole is a figurative language that exaggerates what is actually. In song Red by Taylor Swift again he described his feelings excessively by writing "Forgetting him" with "like trying to know someone you've never met." In this utterance, Taylor described that forgetting the man she loved was like knowing someone she never met. This is impossible and that is too much. Taylor uses these words to attract the attention of listeners and Taylor wants listeners to understand that forgetting someone who is loved is impossible. Based on experts, Rozakis (1995: 28) says that "Figurative language expresses one thing in another than usual to achieve special meaning". Taylor uses words that are different from the ordinary and expresses them with words that are categorized as hyperbole, which are excessive words intended to attract the attention of the listeners.

"Memorizing him was as easy as knowing all the words to your old favorite song"

As we know, hyperbole is one figure that implies excessive ideas. In the above statement, it can be seen that the quotation above is hyperbole from the comparison of "Memorizing him" to "as easy as knowing all the words for your old favorite song " which Taylor keeps memories of with the man she loves is as easy as remembering every word from an old song. This statement is an excessive statement. We as humans cannot use the brain $100 \%$ and remember things in detail. Gie (1995) argues that no matter how strong someone's memory at a time later that memory will experience a process of forgetfulness. Memory at one time can no longer present a statement that is needed because of forgetting. Forgiveness occurs because there is no use. This is explained in the theory of passive decay theory that memory makes a physical trace in a person's brain which is gradually erased by the passage of time. Therefore, the statement on Taylor Swift's surface is excessive. Back to the notion of figurative language, Rozakis (1995: 28) says that "Figurative language expresses one thing in another than usual to achieve special meaning". Therefore, Taylor uses a language that is different from the usual word to get a dramatic impression and so the listener understands the purpose that Taylor wants to convey with all her heart.

\section{CONCLUSION}

Figurative language has several goals to help convey meaning. The use of figurative language by the author is a way to convey ideas in writing. The purpose of figurative language is to develop certain impressions, beautify pronunciation and attract attention from readers. The use of beautiful figurative language in any form title will usually appeal to readers or listeners. Not only in songs, but figurative languages are also used in many literary works such as short stories, poems, and drama scripts.

After analyzing figurative language in song Red by Taylor Swift according to Rozakis's theory the conclusion is 13 data found in the song Red by Taylor Swift. However, the writer only takes 9 data to be analyzed namely 3 metaphors, 3 similes, and 3 hyperboles. The dominant figurative language in this song is simile and hyperbole. 


\section{REFERENCES}

Abrams, M. H. (1999). A Glossary of Literary Terms/Seventh Edition.New York: Heinle\&Heinle.

Dennis. (1996). Language and Diction in Linguistics. Barkeley: University of California.

Harmer, Jeremy. (2006). The Practice of English Language Teaching ( $3 \mathrm{rdEd})$. New York: Longman Publishing.

Keraf, Gorys. (2001). Diksi dan Gaya Bahasa. Jakarta: PT. Gramedia Pustaka.

Lubis, Syahrul Efendi. (2019). An Analysis of Figurative Language in Phil Collins' Selected Song Lyrics. Jurnal Ilmiah Simantek. 3(1). 23-30.

Moleong, Lexy J. (2009). Metode Penelitian Kualitatif. Bandung Remaja Rosdakarya.
Perrine, Laurence. (1982). Sound and Sense: An Introduction to Poetry, 6th Edition. San Diego, California: Harcourt College Publishers.

Peter. (2002). Figurative Language and Semantics, pp.12. Boston: Little Brown and Company.

Rozakis, Laurie. E. (1995). How to Interpret Poetry. New York: A Simon \& Schuster Macmillan Company.

Sadiasih, Ni Komang Putu Mulya, and Dewi, Putu Chrisma. (2016). Figurative Language in Song Lyrics By Rihanna And Katy Perry. Litera: Jurnal Litera Bahasa dan Sastra. 2(2). 93-97.

Siallagan, Sari Rahita, Manurung, Sulastri, Sinaga, Juwita Boneka. (2017). Analysis of Figurative Language and Imagery in Taylor Swift's Songs. Anglo Saxon: Jurnal Ilmiah Program Studi Pendidikan Bahasa Inggris. 8(1). 55-67 